University of Montana

ScholarWorks at University of Montana

8-1999

\title{
Using Atlas Data to Model the Distribution of Woodpecker Species in the Jura, France
}

Claudine Tobalske

Bret W. Tobalske

University of Montana - Missoula, bret.tobalske@mso.umt.edu

Follow this and additional works at: https://scholarworks.umt.edu/biosci_pubs

Part of the Biology Commons

Let us know how access to this document benefits you.

\section{Recommended Citation}

Tobalske, Claudine and Tobalske, Bret W., "Using Atlas Data to Model the Distribution of Woodpecker Species in the Jura, France" (1999). Biological Sciences Faculty Publications. 294.

https://scholarworks.umt.edu/biosci_pubs/294

This Article is brought to you for free and open access by the Biological Sciences at ScholarWorks at University of Montana. It has been accepted for inclusion in Biological Sciences Faculty Publications by an authorized administrator of ScholarWorks at University of Montana. For more information, please contact

scholarworks@mso.umt.edu. 


\title{
USING ATLAS DATA TO MODEL THE DISTRIBUTION OF WOODPECKER SPECIES IN THE JURA, FRANCE ${ }^{1}$
}

\author{
Claudine Tobalske ${ }^{2}$ \\ Parc Naturel Régional du Haut-Jura, 39310 Lajoux, France, and Wildlife Spatial Analysis Lab, University of \\ Montana, Missoula, MT 59812,e-mail: ctobalsk@yahoo.com \\ BRET W. TOBALSKE ${ }^{2}$ \\ Parc Naturel Régional du Haut-Jura, 39310 Lajoux, France
}

\begin{abstract}
Breeding bird atlases providing distribution data at a regional scale are becoming increasingly common. To assess the ability of such data to develop broad-scale birdhabitat models, we used data from a breeding bird atlas and landscape variables obtained from a geographic information system (GIS) to study the distribution of seven woodpecker species in the Jura, France: the Black (Dryocopus martius), Green (Picus viridis), Greyheaded (P. canus), Great Spotted (Dendrocopos major), Middle Spotted (D. medius), and Lesser Spotted (D. minor) Woodpeckers, and the Wryneck (Jynx torquilla). We used logistic regression to develop predictive models from variables that described each 575-ha atlas cell in terms of forest composition, forest class richness, edge density, and elevation. For all seven species, prediction rates were better than chance; however, improvements over chance classification varied from $14-39 \%$, indicating that predictive ability was species-specific. From our study, we identified limitations inherent to working with gridded data, including grid positioning problems and inability to compute spatial variables. In spite of these limitations, our models could be used for simulations, to improve the atlas itself, and to identify potential suitable habitat.
\end{abstract}

Key words: breeding bird atlas, grid data, habitat model, woodpecker distribution.

Résumé. Les atlas d'oiseaux nicheurs, recueils de données de distribution à l'échelle régionale, sont désormais courrants. Afin d'évaluer l'utilité de ces atlas pour créer des modèles espèce-milieu à large échelle, nous nous sommes servis de données provenant d'un atlas local d'oiseaux nicheurs et de variables extraites via un système d'information géographique (SIG) pour étudier la distribution de sept espèces de pics dans le Jura, France: les pics noir (Dryocopus martius), vert (Picus viridis), cendré (P. canus), épeiche (Dendrocopos major), mar (Dendrocopos medius), et épeichette (Dendrocopos minor), et le torcol fourmilier (Jynx torquilla). Nous avons utilisé la régression logistique pour développer des models prédictifs, en caractérisant chaque maille de 575 ha de la grille de recensement par sa composition forestière, sa richesse en types de forêt, sa densité de lisières, et son altitude moyenne. Pour les sept espèces de pics, nous avons obtenus des taux de prédiction supérieurs à ceux dûs à la chance. Cependant, la capacité de prédiction est dépendante de l'espèce modélisée, l'amélioration apportée par nos modèles variant de $14 \%$ à $39 \%$. Notre étude nous a permis d'identifier des limitations inhérantes à l'utilisation de données présentées sous forme de grille, telles que les problèmes de positionnement de la grille, et la difficulté d'obtenir des variables spatiales. Malgré ces limitations, nos modèles présentent des applications en simulation, pour améliorer l'atlas, et pour identifier des sites potentiellement favorables aux pics.

\section{INTRODUCTION}

Wildlife-habitat relationship (WHR) models, that relate the presence of wildlife species to characteristics of their environment, have become a tool commonly used in wildlife management. WHR models fall into two categories. In

\footnotetext{
${ }^{1}$ Received 17 November 1998. Accepted 12 April 1999.

${ }^{2}$ Current address: Concord Field Station, Harvard University, Old Causeway Road, Bedford, MA 01730.
}

deductive models, existing knowledge of the relationship between a species and its habitat can be used to derive modeling rules, so that the actual location of species does not have to be known. In inductive models, on the other hand, habitat variables are gathered at or around a known species location, and some type of statistical analysis is used to select which variables are the best predictors of the species' occurrence. Inductive models are most useful to help formalize our understanding of a species' relation to its habitat, but require that the species' 
distribution be known. Because it is difficult to obtain distribution data over broad areas, habitat selection studies have often been conducted at a relatively fine scale, for example by collecting environmental data within close proximity of a reproduction site. Broad-scale distribution data such as the outline of a species' range can be used to develop WHR models, but are too crude to be used for habitat management.

Another type of broad-scale distribution data is becoming available, and with a level of detail far superior to that of traditional range maps. Distribution atlases, in the form of systematically sampled grids, are now common, thanks to the coordinated efforts of dedicated volunteers. The size of the cells within the grid varies, usually from 1 or $2 \mathrm{~km}$ for local or regional studies (Glayre and Magnenat 1984, Thomas and Abery 1995) to as large as $30 \mathrm{~km}$ for entire countries (Robertson et al. 1994). Several recent studies have looked at the potential of such atlases to provide information other than distribution per $s e$, including prediction of species distribution from incomplete atlas data (Osborne and Tigar 1992), estimation of rate of species decline (Thomas and Abery 1995), study of seasonal patterns of migration (Underhill et al. 1992), estimation of population size (Robertson et al. 1994), and impact of commercial afforestation on bird species diversity (Allan et al. 1997).

Likewise, Geographic Information Systems (GIS), computer-based systems for the manipulation and analysis of spatially-distributed data (Johnson 1990), have revolutionized the analysis of habitat data. In a GIS, geographical elements (such as forest patches, roads, tracts of land ownership) are described in terms of their spatial location ( $\mathrm{x}-\mathrm{y}$ coordinates), their characteristics (cover type, size, etc.), and their spatial relationship with respect to other features in the map (topology). It is the ability to generate topology that distinguishes a GIS from other types of computer graphics (Burrough 1986). Three methods are available to build a GIS database: (1) digitizing (the process by which elements on a paper map are assigned $x-y$ coordinates in the computer), (2) classifying satellite images (clustering and labeling reflectance values from a raw satellite image to obtain a land cover map), and (3) using a Global Positioning System to obtain $x-y$ coordinates for objects in the field. The resulting digital information is stored in individual layers. Typical GIS layers used in WHR studies may include land cover, topographic variables (elevation, slope, aspect), human features (such as roads), stream network, and species distribution (such as nest sites, radio-locations, or grid cells coded for species presence). Overlay procedures are used to extract habitat characteristics at each species location; the resulting data are usually transferred to a statistical software for analysis. The power of a GIS lies in its ability to analyze large datasets (many species locations, or data collected over broad areas as in the case of distribution atlases) in very little time.

A breeding bird atlas was recently released for the Jura département (hereafter Jura), a $5,055-\mathrm{km}^{2}$ French administrative entity encompassing a variety of land cover types over a broad altitudinal gradient. According to the atlas, seven species of woodpeckers (Picidae) breed in the Jura: the Black Woodpecker, Dryocopus martius; Green Woodpecker, Picus viridis; Grey-headed Woodpecker, P. canus; Great Spotted Woodpecker, Dendrocopos major; Middle Spotted Woodpecker, Dendrocopos medius; Lesser Spotted Woodpecker, Dendrocopos minor; and Wryneck, Jynx torquilla. In this study, we used the distribution data for these seven species and landscape-scale habitat variables in a GIS to develop inductive WHR models in order to test the usefulness of atlas data in predicting species distributions. Woodpeckers were good candidates for our models because they vary in their ecological requirements such as the degree of dependence upon forest, the level of habitat specialization, and the scale of habitat use. Woodpecker species are also of conservation interest, as their populations have shown signs of decline in many countries worldwide (Carlson and Aulén 1990). In addition, habitat requirements of woodpecker species in Europe are well known, which allowed us to compare habitat data extracted at the scale of the atlas grid with the existing scientific and anecdotal knowledge of habitat associations, thereby verifying the biological relevance of the variables.

\section{METHODS}

\section{STUDY AREA}

Located in the eastern part of France, the Jura can be divided into several physiographic regions which follow an altitudinal gradient (range $180-1,495 \mathrm{~m})$ from northeast to southwest: the 


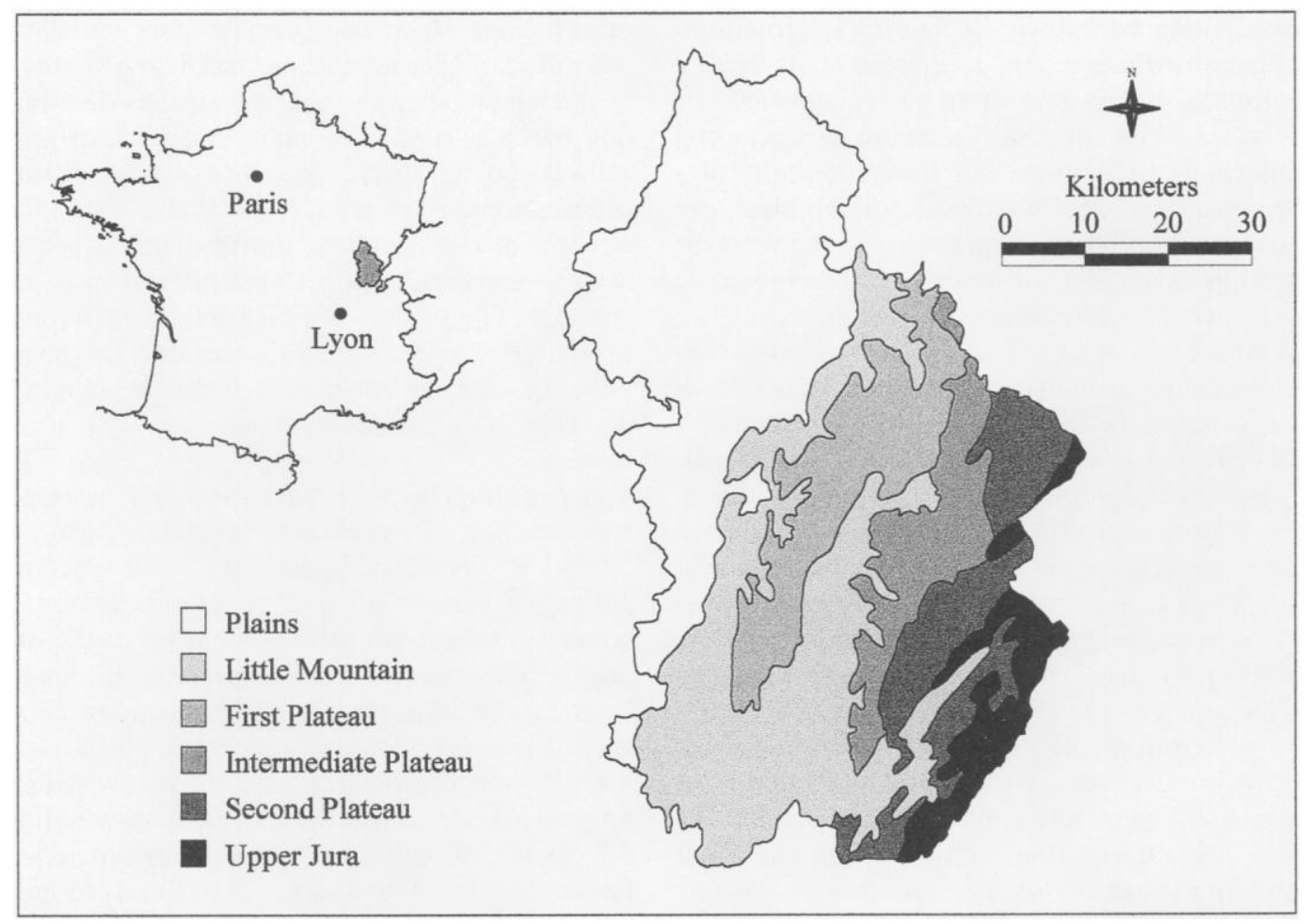

FIGURE 1. Location of the study area in France and physiographic entities of the Jura (adapted from IFN 1993).

Plains, Little Mountain, First, Intermediate, and Second Plateaux, and Upper Jura regions (Fig. 1). This gradient of increasing elevation influences climate, vegetation, and patterns of human land use. With $45 \%$ forest cover (Jovéniaux 1993), the Jura is one of the most forested départements in France. Highly managed deciduous forests (rich in oak, Quercus spp.) dominate areas below $450 \mathrm{~m}$ and, as elevation increases, are replaced with beech (Fagus sylvatica) and mixed forests (beech, white fir Abies alba). Norway spruce (Picea abies) predominates from $800 \mathrm{~m}$ to $1,300 \mathrm{~m}$. Several large forested areas of the First Plateau that were once deciduous have been largely converted to monocultures of fir following World War II. High elevation coniferous forests dominated by Norway spruce grow in the wettest and coldest portions of the Jura; these uneven-aged stands are managed through selective cutting. Large tracts of agricultural crop lands are located in the Plains; elsewhere, agricultural tracts are small and devoted essentially to cattle grazing. The Jura is lightly developed compared to other French départements.

\section{DIGITAL DATABASE}

The distribution maps presented in the Breeding Bird Atlas of the Jura are composed of 945, 575ha cells $(2.3 \times 2.5 \mathrm{~km})$. Bird censuses were conducted yearly from 1985 to 1992 inclusive by members of the Groupe Ornithologique du Jura (full details available in Jovéniaux 1993). A thorough examination of the results was done at the end of each field season to ensure that all cells were censused with the same intensity regardless of topography and to limit the observer bias that could be introduced by a pre-acquired knowledge of the avifauna of certain cells (Jovéniaux 1993, pers. comm.). As users of the published atlas, we made the assumption that the information presented in the maps was accurate, and we did not conduct additional testing of the quality of the atlas. We used the GIS software PC Arc/Info 3.4.2 (ESRI 1994) to generate digital versions of the distribution maps for the sev- 
en woodpecker species, in which each cell of the census grid was assigned one of two values: 0 (absence) or 1 (presence).

Because habitat data were lacking for part of the cells that overlapped the border of the Jura, we eliminated 89 cells from analysis. For each of the 856 remaining cells, we extracted the following 16 habitat variables in the GIS: percent composition of 13 forest classes, forest class richness (the number of different forest classes), edge density, and mean elevation. A forest cover map, recently released for the whole Jura at a 1: 200,000 scale, was obtained from the Inventaire Forestier National (IFN) and digitized using PC Arc/Info 3.4.2. (ESRI 1994). Every forest patch of the paper map resulted in a polygon on the GIS digital map. These polygons were then individually coded in the GIS according to the following 13-class legend (IFN 1980): mature deciduous forests (MatDecid), where mature, large-diameter trees $(>45 \mathrm{~cm}$; mostly oak Quercus spp.) compose more than $50 \%$ of the canopy; plain coppice (Coppice), also dominated by oak, but with a lower proportion of large-diameter trees and a canopy cover less than 50\%; xeric forests (Xeric), characterized by small-diameter trees $(<25 \mathrm{~cm})$ and often a dense understory of boxwood (Buxus sempervirens); scree forests (Scree), restricted to humid scree slopes; mountain deciduous forests (MtnDecid), rich in oak and beech of medium-size diameter (25-45 $\mathrm{cm}$ ), often with a dense coppice of beech; beech forests (Beech), pure or mixed with conifers; fir forests (Fir), dominated by conifers, of which at least $75 \%$ are white fir; spruce forests (Spruce), dominated by conifers, of which at least $75 \%$ are Norway spruce; shelterwood cuts (ShelterCut), in which conifers (usually fir) are planted under an overstory of mature deciduous trees that is eventually removed; other cuts (OtherCut), any other type of regeneration cut, such as clearcuts, or plantations in open fields; patchy forests (Patchy), small woodlots and clumps of trees of varied composition (although predominantly deciduous), used for wood production by local people; riparian and heterogeneous forests (RipHetero), usually small clumps of trees connected by a network of edges or wooded pastures; and nonforested (Open).

Forest class richness was computed for each cell as a measure of habitat fragmentation. Edge density was obtained after combining all the forest classes into one (edge being the limit be- tween forest and nonforest). The GIS was used to compute, for each cell, the total length of the line(s) representing the boundary between patches of forest and patches of nonforest. This value (in meters) was divided by the area of the cell (in hectares) to obtain edge density $\left(\mathrm{m} \mathrm{ha}^{-1}\right)$. Finally, a map of elevation was produced by manually overlaying a grid of points printed on an acetate sheet on top of 1:100,000 topographic maps and recording elevation at each point. The grid was created by systematically locating 16 points within each atlas cell, which roughly corresponded to 1 point every $600 \mathrm{~m}$. These 16 values were averaged to obtain a mean elevation for each cell.

\section{STATISTICAL ANALYSES}

We used the logistic regression (LR) procedure (SPSS 1990) to create the models because this multivariate statistical technique permits the prediction of binary attributes such as presence/absence (McCullagh and Nelder 1983). LR is particularly suited to data in which the distribution is highly skewed and includes many zeros (Stowe et al. 1993, Green et al. 1994), which was the case for the forest cover data. Variable reduction followed Hosmer and Lemeshow (1989): (1) variables were selected based on the statistical significance of their effect in univariate LR analysis (Wald statistic, $P \leq 0.05$ for individual tests and not overall experimentwise error), (2) one of a pair of strongly correlated variables $(r>0.7)$ was eliminated, (3) perfectly discriminated variables were excluded, and (4) variables judged to be ecologically important, even if not statistically significant in the univariate LR analysis, were kept, as long as the sign of the regression coefficient was consistent with knowledge of the species' habitat requirements. We used combinations of the selected variables to create several models for each species, based on a priori hypotheses about woodpecker-habitat relationships we derived from published literature. We selected a "best model" by comparing the predictive capabilities of the model (percent presence and absence correctly classified) and the significance of the variables entering it (based on the partial correlation between the dependent and the independent variables; $R$ statistic in SPSS). Prediction maps were obtained by recoding, in the GIS, each cell with the corresponding probability of presence $P=$ $1 /\left(1+\mathrm{e}^{-\mathrm{z}}\right)$, where $z$ represents the regression 
TABLE 1. Significance of the Wald statistic of univariate logistic regressions for 16 variables for seven woodpecker species in the Jura, France. ${ }^{a}$

\begin{tabular}{|c|c|c|c|c|c|c|c|}
\hline Variable & $\begin{array}{c}\text { Black } \\
\text { Woodpecker }\end{array}$ & $\begin{array}{c}\text { Green } \\
\text { Woodpecker }\end{array}$ & $\begin{array}{l}\text { Grey-headed } \\
\text { Woodpecker }\end{array}$ & $\begin{array}{c}\text { Great } \\
\text { Spotted } \\
\text { Woodpecker }\end{array}$ & $\begin{array}{c}\text { Middle } \\
\text { Spotted } \\
\text { Woodpecker }\end{array}$ & $\begin{array}{c}\text { Lesser } \\
\text { Spotted } \\
\text { Woodpecker }\end{array}$ & Wryneck \\
\hline Elevation & $+* * *$ & $-* * *$ & $-* * *$ & $-* * *$ & $-* * *$ & $-* * *$ & $-* * *$ \\
\hline Richness & + & + & $-*$ & + & $-* * *$ & -* & - \\
\hline EdgeDen & $+*$ & + & - & + & $-* * *$ & $-*$ & - \\
\hline MatDecid & - & + & $+* * *$ & $+* * *$ & $+* * *$ & $+* * *$ & - \\
\hline Coppice & $-*$ & + & $+* * *$ & $+* * *$ & $+* * *$ & $+* * *$ & - \\
\hline Xeric & $+*$ & + & $\mathrm{n} / \mathrm{a}^{\mathrm{b}}$ & - & $\mathrm{n} / \mathrm{a}^{\mathrm{b}}$ & - & - \\
\hline Scree & - & $+*$ & - & + & - & + & + \\
\hline MtnDecid & $-*$ & + & - & + & $-*$ & $-*$ & - \\
\hline Beech & $+* * *$ & $-* * *$ & - & + & - & -* & $-*$ \\
\hline Fir & $+* * *$ & $-* * *$ & - & + & $\mathrm{n} / \mathrm{a}^{\mathrm{b}}$ & $-* * *$ & $-*$ \\
\hline Spruce & $+* * *$ & $-* * *$ & - & - & - & - & - \\
\hline ShelterCut & - & + & + & $+*$ & - & - & - \\
\hline OtherCut & + & - & - & $+*$ & - & + & - \\
\hline Patchy & $-*$ & $+*$ & - & - & $-*$ & + & $+* * *$ \\
\hline RipHetero & - & $+*$ & - & - & $-*$ & - & - \\
\hline Open & $-* * *$ & $+* * *$ & - & $-* * *$ & -**** & + & $+* * *$ \\
\hline
\end{tabular}

$+1-:$ sign of the coefficient of the variable in the regression equation.

${ }^{b}$ Perfectly discriminated variables.

$* P<0.05, * * * P<0.001$.

equation. Cells were classified as "predicted presence" or "predicted absence" using cut-off points selected to maximize both the number of presences and absences correctly classified.

Because high classification rates can be obtained by chance when number of presences and absences are unequal (Morrison 1969, Capen et al. 1986), we estimated the improvement of the models over chance using Cohen's Kappa $(K)$ statistic (Titus et al. 1984). A $K>0$ indicates fewer misclassifications than if cells were classified by chance alone. We tested the null hypothesis that $K=0$ using a $Z$-test.

We used chi-square tests to assess the fit of each model to the logistic curve (Loftsgaarden and Andrews 1992). Model probabilities were ranked, split into eight groups, and summed within each group to obtain predicted presences; this value was subtracted from 1 to obtain predicted absences. Observed values were the number of true presences and absences within each group. A good fit of the model to the logistic curve results in a small chi-square value, that is, a large $P$ value.

\section{RESULTS}

The output of univariate LR differed among species (Table 1), indicating that despite the coarseness of the scale of analysis, the habitat variables could be used to discriminate among species. A review of the published scientific litera- ture confirmed that variables statistically significant at $P \leq 0.05$ were meaningful with regard to the ecology of the species (Tobalske 1998).

The best models obtained from multiple LR used 2 to 6 variables (Table 2). Model performances differed among species, but all the models classified presences and absences better than chance alone $(K>0$; Table 3$)$. Improvement over chance classification ranged from $39 \%$ for the Black Woodpecker, to only $14 \%$ for the Wryneck, which was still a statistically significant improvement $(P \leq 0.001)$. Models for the Black and Middle Spotted Woodpeckers were most successful at correctly classifying presences and absences $(K>0.3$; Table 3). Errors of omission (presences predicted as absences) and commission (absences predicted as presences) occurred for every species (Table 3; Fig. 2).

The models fit the logistic curve reasonably well. The pattern of distribution of the residuals was random for all seven species, and there was no statistically significant difference between the logistic curve and the observed results for five of the seven species $\left(\chi^{2}{ }_{6} \leq 10.64, P \geq 0.1\right)$. For the Black and Green Woodpeckers, the statistically significant difference $(P<0.1)$ was due to a large value in one of the 8 intervals. Collapsing this interval with the next one lowered the chi-square value in both cases (from 20.72 to 
TABLE 2. Regression equations of logistic regression models for seven woodpecker species in the Jura, France.

\begin{tabular}{lc}
\hline \hline \multicolumn{1}{c}{ Species } & Equation \\
\hline Black Woodpecker & $-1.1626-(0.0203$ MtnDecid $)+(0.0161$ Beech $)+(0.0329$ Fir $)+$ \\
& $(0.033$ Spruce $)-(0.0142$ ShelterCut $)-(0.0277$ Open $)$ \\
Green Woodpecker & $-1.7149+(0.0556$ EdgeDen $)+(0.0135$ MatDecid $)-$ \\
& $(0.0643$ Spruce $)+(0.0179$ Open $)$ \\
Grey-headed Woodpecker & $-1.3833-(0.0066$ Elevation $)+(0.0212$ MatDecid $)+$ \\
& $(0.0346$ Coppice $)$ \\
Great Spotted Woodpecker & $0.852+(0.0274$ MatDecid $)+(0.0397$ Coppice $)-$ \\
& $(0.0106$ Open $)$ \\
Middle Spotted Woodpecker & $-1.6992-(0.0085$ Elevation $)+(0.0543$ MatDecid $)-$ \\
& $(0.01076$ OtherCut $)$ \\
Lesser Spotted Woodpecker & $-2.0048+(0.0257$ MatDecid $)+(0.0385$ Coppice $)$ \\
Wryneck & $-3.9794-(0.083$ Fir $)-(0.1957$ Spruce $)+(0.1259$ Patchy $)+$ \\
& $(0.0211$ Open $)$ \\
\hline
\end{tabular}

13.39 for the Black Woodpecker and from 15.67 to 10.22 for the Green Woodpecker).

\section{DISCUSSION}

To assess the usefulness of atlas data for predicting the distribution of woodpecker species in the Jura, France, we created wildlife-habitat relationship (WHR) models using 575-ha cell, species distribution maps, and simple, broadscale habitat variables. The models predicted species distribution better than chance alone (Table 3). However, the wide range of Cohen's Kappa values among models revealed that model success was species specific; this represents a practical weakness for the utility of the models for managers of wildlife habitat. Available literature on fine- and broad-scale habitat needs of woodpeckers in Europe helps to explain why there was considerable variation in prediction rates among the models.

The Black Woodpecker is a generalist, in terms of habitat selection, compared to other members of the family (Tjernberg et al. 1993). However, it nests preferentially in large trees with smooth bark, such as beech trees, and tends to avoid excavating in conifers (Cuisin 1988). The forest cover map we used was well suited to modeling its distribution because large beech trees occurred not only in the Beech category, but also in the Fir and Spruce categories (IFN 1980 , pers. observ.) Hence, a grid cell classified as $100 \%$ Fir or Spruce may contain several suitable nesting trees. Even better results would have been obtained, had we excluded the Plains region from the study area (Fig. 1). Previously considered to be a typical mountain species, the Black Woodpecker is currently expanding its European range into lowland deciduous forests (Cuisin 1980, Spitznagel 1990). Its sporadic use of deciduous forest in the Plains region was difficult to model, although presences in cells with a high proportion of MatDecid could be predicted because Open entered the model negatively.

The Middle Spotted Woodpecker is highly dependent on large forests of mature oaks (Short 1982, Wesolowski and Tomialojc 1986). Good prediction results were obtained because such

TABLE 3. Classification results of logistic regression models for seven woodpecker species in the Jura, France.

\begin{tabular}{|c|c|c|c|c|c|c|c|}
\hline Descriptor $^{\mathrm{a}}$ & $\begin{array}{c}\text { Black } \\
\text { Woodpecker }\end{array}$ & $\begin{array}{c}\text { Green } \\
\text { Woodpecker }\end{array}$ & $\begin{array}{l}\text { Grey-headed } \\
\text { Woodpecker }\end{array}$ & $\begin{array}{c}\text { Great } \\
\text { Spotted } \\
\text { Woodpecker }\end{array}$ & $\begin{array}{c}\text { Middle } \\
\text { Spotted } \\
\text { Woodpecker }\end{array}$ & $\begin{array}{c}\text { Lesser } \\
\text { Spotted } \\
\text { Woodpecker }\end{array}$ & Wryneck \\
\hline Eo & 22 & 150 & 7 & 192 & 6 & 56 & 23 \\
\hline Ec & 166 & 164 & 208 & 140 & 81 & 158 & 250 \\
\hline Po & 0.78 & 0.63 & 0.77 & 0.61 & 0.90 & 0.75 & 0.68 \\
\hline $\mathrm{Pc}$ & 0.64 & 0.50 & 0.72 & 0.51 & 0.84 & 0.65 & 0.63 \\
\hline$K \pm \mathrm{SE}$ & $0.39 \pm 0.05$ & $0.27 \pm 0.03$ & $0.16 \pm 0.06$ & $0.20 \pm 0.04$ & $0.36 \pm 0.08$ & $0.29 \pm 0.05$ & $0.14 \pm 0.05$ \\
\hline$Z$ & $8.7 * *$ & $7.8 * *$ & $2.9 *$ & $5.8 * *$ & $4.6 * *$ & $6.3 * *$ & $3.1 *$ \\
\hline
\end{tabular}

a Eo = Errors of omission; Ec = errors of commission; Po = percent correct classification observed; Pc = percent correct classification due to chance

alone; $K=$ Cohen's Kappa. See Titus et al. (1984) for a detailed description of the computations involved.
$* P<0.05, * * P<0.001$. 

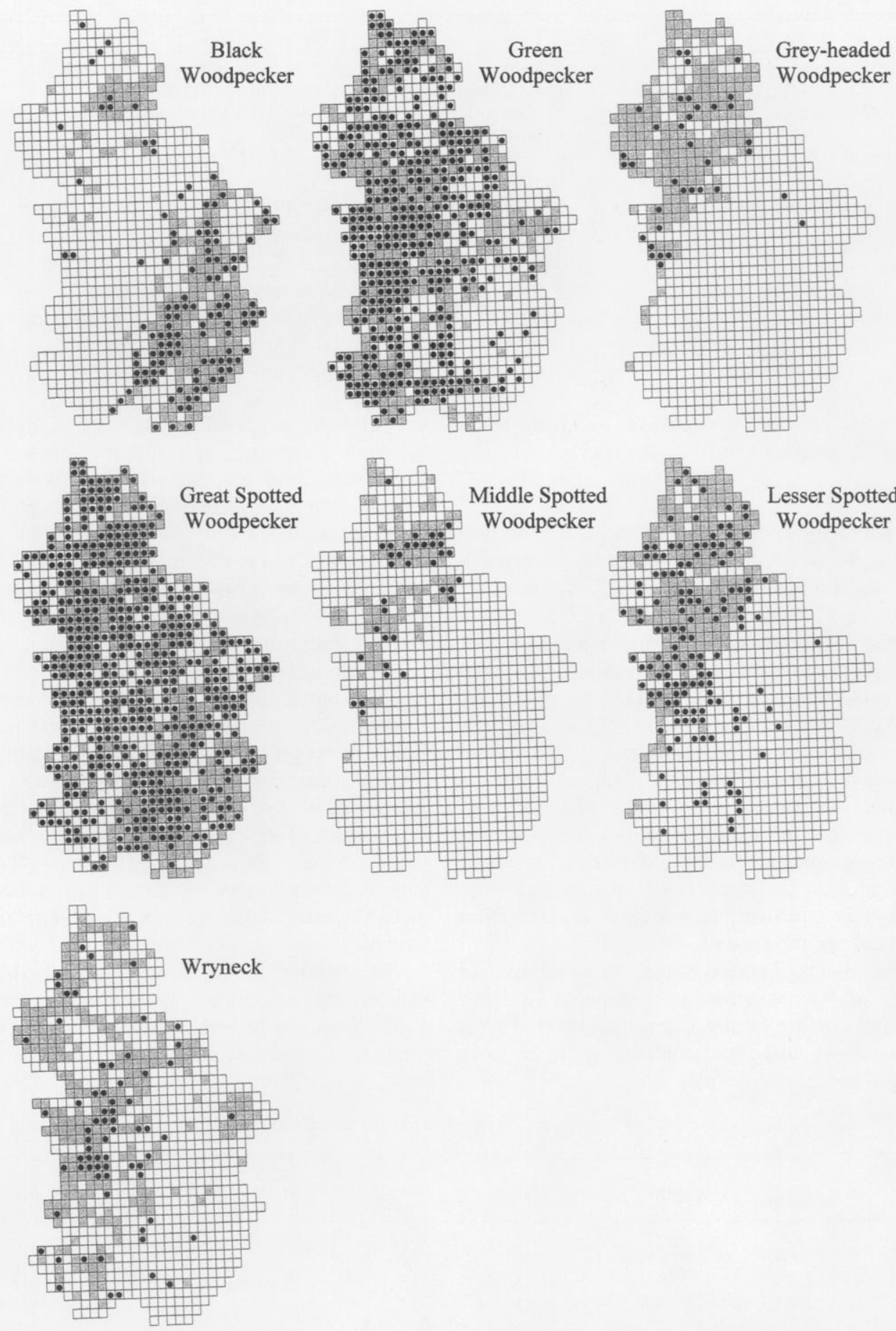

FIGURE 2. Predicted distributions of seven woodpecker species in the Jura, France, obtained by recoding each cell of the distribution maps with the output of a logistic regression model. Shaded: predicted presence. Dot: true presence. 
forests entered the pool of variables from which the models were built (MatDecid); in fact, univariate logistic regression showed that this sole variable correctly predicted $85.7 \%$ of presences and $87.6 \%$ of absences for this woodpecker. The large oak trees required by the Middle Spotted Woodpecker for nesting form the basis of the definition of the MatDecid category (see Digital Database above).

The Green Woodpecker is an edge species that avoids dense, unbroken forests, especially coniferous ones, and prefers low elevation, deciduous stands (Cramp 1985). The model reflects these preferences (Table 2). Although many small patches of suitable habitat were probably not mapped at the 1:200,000 scale of the forest cover map, the positive correlation between the species' presence and the variable Open improved the predictive accuracy of the model.

The Great Spotted Woodpecker has been described as the most ubiquitous European woodpecker, both in terms of feeding requirements and breeding habitat selection (Török 1990, Angelstam and Mikusinski 1994); it occupies forests of any structure and size as long as a few old trees are present (Cramp 1985, Jovéniaux 1993). In our study, it was the most common of the seven species (the only species with more presences than absences) and it occurred in every mapped forest class. This lack of strong habitat preferences, at the 575-ha scale, made its distribution difficult to predict. Although the model still performed better than chance, we suspect that if it had been built using density of observations rather than presence-absence data it may have been more sensitive to small differences in habitat preferences, and thereby more accurate. In general, modeling the distribution of very common species that were censused in a large number of atlas cells may prove difficult. In such instances, patterns of species-habitat associations may be revealed at a coarser or finer scale.

Difficulties arose when developing models for the remaining three species (Grey-headed and Lesser Spotted Woodpeckers, and Wryneck) because their presences are tied to specific microhabitats that were not mapped by the IFN. We found a correlation between the Grey-headed Woodpecker's presence and mature deciduous and coppice forests, as suggested by Angelstam and Mikusinski (1994). The variables used in the species' models (Elevation, MatDecid, Coppice) were biologically sound, but they predicted a much broader distribution than that of the original atlas map (Fig. 2). A closer fit between observed and predicted would have been obtained, had we been able to model the species' distribution at the microhabitat level. The Grey-headed Woodpecker is known to prefer more humid areas, such as beech, poplar, alder, or willow patches along streams and rivers (Cramp 1985, Jovéniaux 1993, Winkler et al. 1995). A similar problem was encountered for the Wryneck. This species is currently declining in the Jura, partially because of small-scale habitat changes that affect both feeding and breeding habitat (Jovéniaux 1993). The Wryneck requires both suitable nest holes (which it is unable to excavate), and patches of warm, dry ground to find the ants that compose the majority of its diet (Cramp 1985). It is therefore sensitive to the disappearance of small patches of dry grasslands and of orchards, and even to the felling of individual trees if those provided a suitable nesting cavity. Clearly, a 1:200,000 scale forest map cannot capture such fine-scale habitat characteristics.

The Lesser Spotted Woodpecker, a species that preferentially excavates highly decayed wood, is often found in riparian forests (Cramp 1985, Jovéniaux 1993), where snags are more common because of less intensive harvesting of the stands (Spitznagel 1990, Olsson et al. 1992). At the 575-ha scale, however, a negative correlation was observed between the species' presence and the RipHetero variable (Table 1). A probable explanation is that riparian habitat makes up only a small fraction of the area covered by this forest class, most of it being wooded pastures. Many small riparian patches have not been mapped at the 1:200,000 scale of the IFN map. The model incorporates only such broad forest types as MatDecid and Coppice, causing omission errors where small forest patches with decayed wood were not mapped, and commission errors where one of these two types occurred, even though they may not contain trees suitable for nest excavation (Table 3, Fig. 2). In all three cases, a more detailed forest map may have improved the fit of the models, but availability of fine-scale data for broad areas is often limited. If small patches of suitable habitat had been mapped, but had been located in an atlas cell otherwise largely dominated by patches of unsuitable habitat, the model would probably 
have misclassified this cell. Such a "swamping" problem is inherent to working with gridded data.

We identified additional limitations of atlas data, such as grid positioning problems and inability to compute most spatial habitat variables. The census grid used in the Breeding Bird Atlas of the Jura was obtained by subdividing existing 1:50,000 scale maps into equal-sized blocks (Jovéniaux 1993). The position of the cells has no relation to the spatial distribution of land cover types; indeed, only in a highly anthropogenic environment would habitat patches have geometric shapes. Consequently, species were sometimes present in cells dominated by unsuitable habitat. The Black Woodpecker provides a good example of such a grid positioning problem. In the Jura, this species nests sporadically in large oak patches of the Plains region. Some of these untypical presences could be predicted because the cells were almost entirely forested, and Open entered the models negatively. On the other hand, if a presence was recorded in an atlas cell that included mostly open habitat, for example at the edge of a large forest patch, the model did not predict a presence for that cell. Such prediction failures will always occur with gridded data.

The habitat variables used in the present study are simple and typical of any large-scale wildlife-habitat relationship study, especially when grid cells are used as units. The spatial patterning of habitat types across landscapes, however, is thought to exert a strong influence on the distribution of the vertebrate populations inhabiting those landscapes (Wiens 1989). Little is known of the relationship between the distribution of woodpecker species and spatial characteristics of the landscape other than patch area and patch isolation (Haila et al. 1987, Wiktander et al. 1992, Hinsley et al. 1995). Unfortunately, bird atlas data are poorly suited to assess the influence of spatial characteristics of the landscape on species distribution. Even basic spatial information such as patch size cannot be obtained for the cells of a grid because each cell usually overlaps many patches. Computing mean patch size within cells could lead to confusing results; a cell with several, medium-sized patches could give the same outcome as one with one large patch and many small ones. Similarly, nearestneighbor and patch type adjacencies cannot be obtained because the exact patch in which the nest was located is unknown. Edge density and forest class richness were the only two landscape variables that could be easily calculated from our data. Number of patches was not included in the analysis because it was strongly correlated with forest class richness $\left(r_{\mathrm{s}}=0.75\right.$, $P \leq 0.001, n=856)$ and edge density $\left(r_{\mathrm{s}}=\right.$ $0.88, P \leq 0.001, n=856$ ). The influence of the amount of forested habitat was measured by the variable Open, which turned out to be negatively associated with the presence of forest woodpeckers (Black, Great, and Middle Spotted Woodpeckers) and positively associated with that of species known to occur in more open landscapes (Green Woodpecker and Wryneck). It was not possible, however, to verify whether Middle Spotted Woodpeckers preferred patches of 30 ha or more, avoided those below $5 \mathrm{ha}$, and did not favor those more than $3 \mathrm{~km}$ apart, as reported by Cramp (1985). The negative association between the species' presence and edge density and forest class richness (Table 1) is the only indication of the species' possible avoidance of small patches.

Despite the limitations outlined above, the models we derived from the Breeding Bird Atlas of the Jura have potential applications. They provide quantitative information for the entire département that can be compared with anecdotal and localized information. For example, the conversion of deciduous forests to coniferous ones has been suggested as a factor contributing to the decline of the Middle Spotted Woodpecker (Pettersson 1985, Clergeau and Chefson 1988, Jovéniaux 1993). Because the model reflects the importance of mature deciduous forests to the species, and includes OtherCut (which can consist of conifer plantations on previously open grounds), it could be used to simulate the consequences of additional conversions/plantations on the species' breeding distribution. Spatial simulation modeling may be one of the most powerful applications of GIS in future land and resource management (Parker 1988). In our study, it would be simple to modify the existing forest map, run the models, and compare the resulting distribution map to that obtained with the original forest map. The models were not validated with an independent data set, so it would be difficult to assess how much confidence should be put in the output of such a simulation (Morrison et al. 1992). Simulation modeling could nevertheless be used as an ex- 
ploratory tool, as a warning signal of what may happen under various management procedures, and lead forest managers to think more critically about the consequences of broad-scale modifications of the landscape. The conversion of much of the First Plateau deciduous forests to uniform conifer stands after World War II is an example of such an alteration of the semi-natural landscape. It may have contributed to the decline of the Grey-headed Woodpecker in the Jura, because of the species' preference for deciduous forests.

Although we did not undertake our study to provide specific management guidelines for woodpecker species in the Jura, our results provide potentially useful information that could be applied toward woodpecker habitat conservation. For example, habitat fragmentation is among the most serious causes of the loss of biological diversity (Harris and Silva-Lopez 1992). The variables EdgeDen and Richness can be used as indicators of forest fragmentation in the Jura. Woodpecker species negatively associated with these variables (such as the Greyheaded, Middle Spotted, and Lesser Spotted Woodpeckers; Table 1) seemingly would benefit from the maintenance of large patches of their preferred forest types, especially lowland deciduous forest. On the other hand, the Black Woodpecker often occurs in fragmented forest (Haila et al. 1987), but only up to a certain level of fragmentation (Tjernberg et al. 1993). The positive association we observed between the Black Woodpecker and the variable EdgeDen (Table 1) should not, therefore, be seen as an indication that fragmentation benefits this species. Rather, the Black Woodpecker may tolerate a greater degree of fragmentation than species which were negatively associated with EdgeDen.

Another possible use of models developed from atlas data is to improve the atlas itself. Because the output of logistic regression is not categorical, but probabilistic, the models can be used to highlight cells with a higher probability of species' presence. This was done in Lesotho, where the difficulty to access the most rugged parts of the country and an uneven repartition of the number of observers may have biased species distribution estimates (Osborne and Tigar 1992). During the creation of the Jura atlas, much time and effort was devoted to ensure as thorough a coverage of the study area as possible. Nevertheless, censuses may have underes- timated the distribution of such secretive and rare species as the Grey-headed and Middle Spotted Woodpeckers (Jovéniaux, pers. comm.). Without first-hand knowledge of the area, it is difficult to know whether absence cells were comprised of truly unsuitable habitat. There can be three reasons for absence cells: the cell lacks suitable habitat, the cell contains suitable habitat, but was unoccupied during the time frame of the census (this is especially likely for species exhibiting metapopulation dynamics), or, the species was present, but went undetected. Presenting distribution data as probabilities of occurrence, such as the output of LR models built from the original presence/absence data, is one way to limit the problem of false absences (Osborne and Tigar 1992). The maps presented in Figure 2, showing cells with high probabilities of presence but where no bird was detected (errors of commission), would be useful to target future censuses. In addition, because population sizes of species tend to fluctuate, it may be valuable to identify and protect areas of suitable habitat, even if they are not occupied at the moment. This is especially important for species that have declined but may be in a recolonizing phase (Anthony et al. 1982). Identifying cells with a high probability of presence would help biologists prioritize areas where finer-scale, time-consuming habitat investigations should be conducted.

Overall, our study showed that analyzing woodpecker distribution data from a breeding bird atlas in conjunction with habitat variables in a GIS provides a relatively simple way to build habitat-association models, as long as one is aware of the limitations of working with gridded data, at a single, imposed scale. It may not be possible to develop models for species that are not showing strong correlations with habitat variables at that scale. However, with increasing numbers of species becoming threatened by human alteration of their environment, and little time or funding available for detailed, fine-scale studies, it will become crucial to make the best use of existing information.

\section{ACKNOWLEDGMENTS}

We are grateful to A. Jovéniaux and the members of the Groupe Ornithologique du Jura for permitting use of data from the atlas; this study would not have been possible without their long-term censusing efforts. We also thank the Parc Naturel Régional du Haut-Jura and the Wildlife Spatial Analysis Lab for providing access 
to a GIS station. R. Dixon, W. Koenig, R. Redmond, and P. Zwartjes provided helpful comments on earlier versions of the manuscript. This study was funded is part by a Fulbright Fellowship to BWT.

\section{LITERATURE CITED}

Allan, D. G., J. A. Harrison, R. A. Navarro, B. W. VAn Wilgen, and M. W. Thompson.1997. The impact of commercial afforestation on bird populations in Mpumalanga province, South Africainsights from bird-atlas data. Biol. Conserv. 79: 173-185.

ANGElstaM, P., AND G. MikusinsKi.1994. Woodpecker assemblages in natural and managed boreal and hemiboreal forest-a review. Ann. Zool. Fennici 31:157-172.

Anthony, R. G., R. L. Knight, G. T. Allen, B. R. McClelland, AND J. I. Hodges.1982. Habitat use by nesting and roosting Bald Eagles in the Pacific Northwest. Trans. N. Am. Wildl. Nat. Resour. Conf. 47:332-342.

Burrough, P. A.1986. Principles of geographical information systems for land resources assessment. Oxford Univ. Press, New York.

CAPEN, D. E., J. W. Fenwick, D. B. InKley, AND A. C. BOYNTON.1986. Multivariate models of songbird habitat in New England forests, p. 171-175. In J. Verner, M. L. Morrison, and C. J. Ralph [eds.], Wildlife 2000: modeling habitat relationships of terrestrial vertebrates. Univ. Wisconsin Press, Madison, WI.

Carlson, A., and G. Aulén.1990. Conservation and management of woodpecker populations. Report 17, Swedish Univ. Agric. Sci., Uppsala.

Clergeau, P., and P. Chefson.1988. Les pics. Série "Comment vivent-ils" Vol. 20. Atlas Visuels Payot Lausanne. Payot Lausanne, Lausanne.

CRAmP, S.1985. The birds of Western Palaearctic. Vol. 4. Oxford Univ. Press, Oxford.

Cuisin, M.1980. Nouvelles données sur la répartition du pic noir (Dryocopus martius (L.)) en France et comparaison avec la situation dans d'autres pays. L'oiseau et R.F.O. 50:23-32.

CuIsIN, M.1988. Le pic noir (Dryocopus martius (L.)) dans les biocénoses forestières. L'oiseau et R.F.O. 58:173-276.

ESRI 1994. PC ARC/INFO 3.4.2. Environmental Sys tems Research Institute, Redlands, CA.

Glayre, D., AND D. Magnenat.1984. Oiseaux Nicheurs de la Haute Vallée de l'Orbe. Nos Oiseaux 398. Fascicule spécial du volume 37.

Green, R. E., P. E. Osborne, and E. J. SEars.1994. The distribution of passerine birds in hedgerows during the breeding season in relation to characteristics of the hedgerow and adjacent farmland. J. Appl. Ecol. 31:677-692.

HAILA, Y., I. K. HANSKI, AND S. RaIVIO.1987. Breeding bird distribution in fragmented coniferous taiga in southern Finland. Ornis Fenn. 64:90-106.

HARRIS, L. D., AND G. Silva-LoPEZ.1992. Forest fragmentation and the conservation of biological diversity, p.199-237. In P. L. Fiedler and S. K. Jain [eds.], Conservation biology. The theory and prac- tice of nature conservation, preservation, and management. Chapman and Hall, New York.

Hinsley, S. A., P. E. Bellamy, I. Newton, and T. H. SPARKS.1995. Habitat and landscape factors influencing the presence of individual breeding bird species in woodland fragments. J. Avian Biol. 26: 94-104.

Hosmer, D. W., AND S. Lemeshow.1989. Applied logistic regression. John Wiley and Sons, New York.

IFN.1980. Département du Jura. Résultats du deuxième inventaire forestier. Tome 1. Ministère de l'Agriculture, Direction des Forêts, Paris.

IFN.1993. Carte Forestière du département du Jura. Ministère de l'Agriculture, Direction des Forêts, Paris.

JoHnson, L. B.1990. Analyzing spatial and temporal phenomena using geographic information systems: a review of ecological applications. Landscape Ecol. 4:31-43.

JovénIAUX, A.1993. Atlas des Oiseaux Nicheurs du Jura. Groupe Ornithologique du Jura, Lons-leSaunier, France

Loftsgaarden, D. O., And P. L. Andrews.1992. Constructing and testing logistic regression models for binary data: applications to the National Fire Danger Rating System. U.S. For. Serv., Intermountain Res. Stn. Gen. Tech. Rep. INT-286, Missoula, MT.

MCCullagh, P., AND J. A. Nelder.1983. Generalized linear models. Chapman and Hall, London.

MorRISON, D. G.1969. On the interpretation of discriminant analysis. J. Marketing Res. 4:156-163.

Morrison, M. L., B. G. MARCOT, AND R. W. MANNAN.1992. Wildlife-habitat relationships. Univ. Wisconsin Press, Madison, WI.

Olsson, O., I. N. Nilsson, S. G. Nilsson, B. PettersSON, A. Stagen, AND U. WikTANDER. 1992. Habitat preferences of the Lesser Spotted Woodpecker Dendrocopos minor. Ornis Fenn. 69:119-125.

OSBORNE, P. E., AND B. J. TIGAR.1992. Interpreting bird atlas data using logistic models: an example from Lesotho, Southern Africa. J. Appl. Ecol. 29:5562.

PARKeR, H. D.1988. The unique qualities of a geographic information system: a commentary. Photogrammetric Engineering and Remote Sensing 54:1547-1549.

Pettersson, B.1985. Extinction of an isolated population of the Middle Spotted Woodpecker Dendrocopos medius (L.) in Sweden and its relation to general theories on extinction. Biol. Conserv. 32: 335-353.

Robertson, A., R. E. Simmons, A. M. Jarvis, And C. J. Brown.1994. Can bird atlas data be used to estimate population size? A case study using $\mathrm{Na}$ mibian endemics. Biol. Conserv. 71:87-95.

SHORT, L. L.1982. Woodpeckers of the world. Delaware Mus. Nat. Hist. Monogr. Ser. No. 4. Del. Mus. Nat. Hist., Greenville, DE.

SPITZNAGEL, A.1990. The influence of forest management on woodpecker density and habitat use in floodplain forests of the Upper Rhine Valley, p. 117-146. In A. Carlson and G. Aulén [eds.], Conservation and management of woodpecker popu- 
lations. Rep. 17, Swedish Univ. Agric. Sci., Uppsala.

SPSS.1990. SPSS 4.0.4. for the Macintosh. SPSS Inc., Chicago.

Stowe, T. J., A. V. Newton, R. E. GReEN, AND E. MAYES.1993. The decline of the corncrake Crex crex in Britain and Ireland in relation to habitat. J. Appl. Ecol. 30:53-62.

ThOMAS, C. D., AND J. C. G. ABery.1995. Estimating rates of butterfly decline from distribution maps: the effect of scale. Biol. Conserv. 73:59-65.

Titus, K., J. A. Mosher, AND B. K. Williams. 1984 Chance-corrected classification for use in discriminant analysis: ecological applications. Am. Midl. Nat. 111:1-7.

TJERnBERG, M., K. JOHNSSON, AND S. G. NILSSON.1993. Density variation and breeding success of the Black Woodpecker Dryocopus martius in relation to forest fragmentation. Ornis Fenn. 70:155-162.

TOBALSKE, C.1998. Modeling the distribution of woodpecker species in the Jura, France, and in Switzerland, using atlas data. Ph.D. diss., Univ. Montana, Missoula, MT.
TöRÖK, J.1990. Resource partitioning among three woodpecker species Dendrocopos spp. during the breeding season. Holarctic Ecol. 13:257-264.

UNDERHILL, L. G., R. P. PRYs-JoNes, J. A. HARRISON, AND P. MARTINEZ.1992. Seasonal patterns of occurrence of Palaearctic migrants in southern Africa using atlas data. Ibis 134(Suppl. 1):99-108.

WesolowsKi, T., AND L. Tomialojc.1986. The breeding ecology of woodpeckers in a temperate primaeval forest-preliminary data. Acta Ornithol. 22:1-21.

WIENS, J. A.1989. Spatial scaling in ecology. Functional Ecol. 3:385-397.

WikTANDER, U., I. N. NiLSSON, S. G. NiLSSON, O. OlsSON, B. Pettersson, AND A. StAGen.1992. Occurrence of the Lesser Spotted Woodpecker Dendrocopos minor in relation to area of deciduous forest. Ornis Fenn. 69:113-118.

Winkler, H., D. A. Christie, AND D. NuRney.1995. Woodpeckers. An identification guide to the woodpeckers of the world. Houghton Mifflin, Boston. 